\title{
Klausula Pembatasan dan Pengalihan Tanggung Jawab Pialang Berjangka dalam Kontrak Baku Pemberian Amanat secara Elektronik On-Line
}

\author{
Siti Anisah dan Catur Septiana Rakhmawati \\ Fakultas Hukum Universitas Islam Indonesia \\ Jln. Tamansiswa No. 158 Yogyakarta \\ anisahraharjo@gmail.com, septianarakhma@gmail.com
}

Naskah diterima: 11/10/2016; revisi: 15/11/2016; disetujui: 22/12/2016

\begin{abstract}
The core problems in this study include first, why the clause of liability limitation is regulated in the Regulation of Bappeti Head No. 107/BAPPEBTI/PER/11/2013 which should provide protection to the parties as the futures trading actors? Second, is the standard contract in the attachment of Regulation of Bappebti Chief No. 107/BAPPEBTI/PER/11/2013 is a binding contract for the traders in the Commodity Futures Trading? This is a normative legal research and its results showed first, the attachment of Regulation of Bappeti Head No. 172/BAPPEBTI/PER/11/2013 is a form of government intervention into the contractual relationship, containing the clause of the liability limitation of one of the parties namely Broker. This regulation gives injustice for investors. Second, this contract should be null and the mechanism of its cancelation is through judicial review to the Supreme Court.
\end{abstract}

Keywords: Standard contract; commodity futures trading; justice; intervention

\section{Abstrak}

Pokok permasalahan dalam penelitian ini: pertama, mengapa klausula pembatasan tanggung jawab pialang berjangka muncul dalam Peraturan Kepala Bappebti No. 107/BAPPEBTI/PER/11/2013 yang seharusnya memberikan perlindungan kepada para pihak sebagai pelaku perdagangan berjangka? Kedua, apakah kontrak standar dalam Lampiran Peraturan Kepala Bappebti No. 107/BAPPEBTI/PER/11/2013 merupakan kontrak yang mengikat bagi para pelaku perdagangan dalam Perdagangan Berjangka Komoditi? Penelitian ini menggunakan metode penelitian hukum normatif. Hasil dari penelitian ini menunjukkan: pertama, Lampiran Peraturan Kepala Bappebti No. 172/BAPPEBTI/PER/11/2013 merupakan bentuk intervensi pemerintah ke dalam hubungan kontraktual, yang memuat klausula pembatasan tanggung jawab salah satu pihak yaitu Pialang Berjangka dan peraturan ini memberikan ketidakadilan bagi para investor. Kedua, kontrak ini seharusnya batal demi hukum dan mekanisme pembatalannya melalui pengajuan judicial review ke Mahkamah Agung.

Kata-kata Kunci: Kontrak standar; perdagangan berjangka komoditi; keadilan; intervensi 


\section{Pendahuluan}

Perdagangan Berjangka Komoditi bertujuan meningkatkan kegiatan suaha Komoditi agar dapat terselenggara secara teratur, wajar, efisien, efektif, dan terlindunginya masyarakat dari tindakan yang merugikan serta memberikan kepastian hukum kepada semua pihak yang melakukan kegiatan Perdagangan Berjangka Komoditi. ${ }^{1}$ Pada tujuan itulah Badan Pengawas Perdagangan Berjangka Komoditi (Bappebti) sebagai lembaga pemerintah memiliki tugas pokok untuk melakukan pembinaan, pengaturan, pengembangan, dan pengawasan Perdagangan Berjangka Komoditi. Melalui kewenangan yang dimiliki oleh Bappebti, dapat dilakukan pengawasan guna mencegah kerugian yang potensial akan diderita oleh masyarakat. ${ }^{2}$

Namun demikian, dilihat dari regulasi yang telah dikeluarkan oleh Bappebti, masih terdapat beberapa norma yang dirasa dapat mengurangi semangat lahirnya Undang-Undang No. 10 Tahun 2011 tentang Perubahan atas Undang-Undang Nomor 32 Tahun 1997 tentang Perdagangan Berjangka Komoditi. Hal dimaksud terdapat dalam Lampiran No. 2 Peraturan Kepala Bappebti No. 107 Tahun 2013 berisi Formulir-Formulir Standar, antara lain Perjanjian Pemberian Amanat secara Elektronik On-Line antara Nasabah dan Pialang Berjangka. Perjanjian Pemberian Amanat secara Elektronik On-Line antara Nasabah dan Pialang Berjangka tersebut berbentuk kontrak standar atau baku.

Lampiran No. 2 Peraturan Kepala Bappebti No. 107 Tahun 2013 menjadi bermasalah karena dalam Lampiran tersebut melampirkan beberapa formulir yang berisi perjanjian bagi para Nasabah dan Pialang Berjangka dimana diatur klausulaklausula yang memberatkan Nasabah, mengandung klausula yang tidak adil, serta membebankan kewajiban dan atau risiko pada salah satu pihak. Meskipun bentuk kontrak tersebut merupakan kontrak baku, namun seharusnya tidak memberikan beban hanya pada satu pihak saja. Hak dan kewajiban yang seimbang di antara

${ }^{1}$ Bagian menimbang Undang-Undang No. 10 Tahun 2011.

${ }^{2}$ Hoffman, Future Trading upon Organized Commodity Markets in the United States, 1932, hlm. 14 memberikan arti "a future is a contract entered into on an organized market to deliver grain at a definite price during a specified future period." Untuk itu, perdagangan berjangka komoditi terutama tidak diselenggarakan untuk melakukan transfer kepemilikan dari objek dalam kontrak; melainkan melibatkan terutama asumsi risiko perubahan harga oleh spekulasi, atau pergeseran risiko tersebut dengan lindung nilai.Federal Regulation of Commodity Future Trading, 60 Yale Law Journal 822, Mei 1951, hlm. 825. 
para pihak harus dijamin keadilan dan kepastian hukumnya. Kesepakatan antara Nasabah dan Pialang harus terwujud meskipun bentuk kontrak dalam Lampiran tersebut adalah kontrak baku.

Berikut ini merupakan contoh klausula-klausula yang memberikan pembatasan atau pelepasan tanggung jawab terhadap pihak yang berhubungan dengan Nasabah dalam Lampiran Peraturan Kepala Bappebti itu: ${ }^{3}$ Pasal 5 tentang Hak Pialang Berjangka Melikuidasi Posisi Nasabah; Pasal 6 tentang Penggantian Kerugian Tidak Menyerahkan Barang; Pasal 7 tentang Penggantian Kerugian Tidak Adanya Penutupan Posisi; Pasal 8 tentang Pialang Berjangka Dapat Membatasi Posisi; Pasal 9 tentang Tidak Ada Jaminan atas Informasi atau Rekomendasi Nasabah, dengan pengakuan terhadap 3 tindakan Pialang Berjangka; serta Pasal 10 tentang Pembatasan Tanggung Jawab Pialang Berjangka.

Kontrak baku yang merupakan bagian tidak terpisahkan dari Peraturan Kepala Bappebti dan berisi klausula pembatasan tanggung jawab pialang berjangka dalam perjanjian pemberian amanat secara elektronik on-line, adalah wujud intervensi pemerintah. Memang benar bahwa tugas dan kewenangan Bappebti sebagaimana telah dijelaskan sebelumnya adalah pengaturan, pengembangan, pembinaan, dan pengawasan kegiatan perdagangan berjangka. Selanjutnya Peraturan Kepala Bappebti merupakan perwujudan fungsi pengaturan. ${ }^{4}$ Akan tetapi, peraturan yang dikeluarkan seharusnya tidak menyentuh ranah privat yang membebankan tanggung jawab secara berat sebelah kepada salah satu pihak, berupa klausul kontrak baku dalam Peraturan Kepala Bappebti No. 107/Bappebti/Per/11/2013.

Hal ini dikarenakan klausul kontrak seharusnya diserahkan kepada para pihak yang melakukan kegiatan perdagangan berjangka komoditi meskipun kontrak tersebut berbentuk kontrak standar. Alasan ini sangat logis mengingat para pihaklah yang akan melaksanakan kontrak yang disepakati, sedangkan Bappebti tidak termasuk para pihak tersebut. Selanjutnya, kontrak atau perjanjian pada dasarnya dibuat berdasarkan kesepakatan para pihak sebagaimana syarat sah perjanjian yang diatur dalam Pasal 1320 KUHPerdata. Seharusnya Peraturan 
Kepala Bappebti berisi rule of game yang memberikan keseimbangan bagi para pihak dalam kontrak. ${ }^{5}$

Nampaknya kehadiran Peraturan Kepala Bappebti No. 107/Bappebti/Per/11/2013 tidak sesuai dengan tujuan Undang-Undang No. 10 Tahun 2011, termasuk peran yang dimiliki oleh Bappebti sebagai regulator di perdagangan berjangka komoditi.

\section{Rumusan Masalah}

Penelitian ini disusun berdasarkan permasalahan sebagai berikut: Pertama, mengapa klausula pembatasan tanggung jawab pialang berjangka justru muncul dalam Lampiran Peraturan Kepala Bappebti No. 107/BAPPEBTI/PER/11/2013 yang seharusnya memberikan perlindungan kepada para pihak sebagai pelakupelaku perdagangan? Kedua, apakah kontrak standar dalam Lampiran Peraturan Kepala Bappebti No. 107/BAPPEBTI/PER/11/2013 merupakan kontrak yang mengikat bagi para pelaku perdagangan dalam Perdagangan Berjangka Komoditi?

\section{Tujuan Penelitian}

Penelitian ini disusun dengan tujuan sebagai berikut: Pertama, memperoleh pemahaman dengan baik mengapa klausula pembatasan tanggung jawab pialang berjangka justru muncul dalam Lampiran Peraturan Kepala Bappebti No. 107/BAPPEBTI/PER/11/2013 yang seharusnya memberikan perlindungan kepada para pihak sebagai pelaku-pelaku perdagangan; Kedua, menganalisis apakah kontrak standar dalam Lampiran Peraturan Kepala Bappebti No. 107/BAPPEBTI/PER/11/2013 merupakan kontrak yang mengikat bagi para pelaku Perdagangan Berjangka Komoditi.

\section{Metode Penelitian}

Jenis penelitian yang digunakan ini adalah penelitian normatif dengan pendekatan yuridis, lebih khususnya konseptual dan perundang-undangan. Data

\footnotetext{
${ }^{5}$ Note, "Prevention of Commodity Futures Manipulation under the Commodity Exchange Act, 54 Harvard Law Review 1373, Juni 1941, hlm. 1375. sebagai perbandingan, awal pengaturan dalam the Commodity Exchange Act antara lain berisi ketentuan untuk mencegah terjadinya manipulasi yang dilakukan oleh tindakan pemerintah, manipulasi sanksi oleh tindakan pemerintah secara langsung, dan pengawasan pemerintah terhadap manipulasi dalam kegiatan bursa berjangka.
} 
yang dikumpulkan dalam penelitian ini berasal dari data sekunder. Data sekunder terdiri dari bahan hukum primer, sekunder dan tersier. Bahan hukum primer berupa peraturan perundang-undangan. Bahan hukum sekunder berupa artikel, buku, penelitian, jurnal, makalah, dan karya ilmiah lainnya yang berkaitan kontrak baku dalam perdagangan berjangka komoditi di Indonesia. Bahan hukum tersier yaitu bahan hukum yang dapat menjelaskan bahan hukum primer dan sekunder, antara lain berupa kamus maupun ensiklopedia. Analisis data dalam penelitian ini bersifat deskriptif kualitatif, yaitu mengumpulkan, mengkualifikasikan kemudian menghubungkan dan menganalisis bahan hukum primer dan teori yang berkaitan dengan masalah, serta menarik kesimpulan untuk menentukan hasil. ${ }^{6}$

\section{Hasil Penelitian dan Pembahasan}

\section{Klausula Pengalihan dan Pembatasan Tanggung Jawab Pialang Berjangka dalam Lampiran Peraturan Kepala Bappebti}

Lembaga-lembaga negara, khususnya di Indonesia, dikelompokkan ke dalam dua pembeda yaitu dari seri segi hierarki dan fungsi. ${ }^{7}$ Pembedaan secara hierarkhi diperlukan untuk menentukan perlakuan hukum secara tepat, terutama mengangkut tata karma keprotokolan dimana pernyataan ini kemudian dikaitkan dengan teori norma sumber legitimasi. ${ }^{8}$ Terdapat dua kriteria yang dipakai yaitu kriteria hierarki bentuk sumber normatif yang menentukan kewenangannya, dan kualitas fungsinya yang bersifat utama atau penunjang dalam sistem kekuasaan negara. ${ }^{9}$ Oleh karena itu, dari segi hierarki kemudian dibagi lagi menjadi tiga lapis yaitu organ lapis pertama disebut lembaga tinggi negara, organ lapis kedua disebut sebagai lembaga negara saja, sedangkan organ lapis ketiga disebut sebagai lembaga daerah. ${ }^{10}$ Selanjutnya, dari segi fungsinya lembaga-lembaga negara tersebut ada yang bersifat utama atau primer dan ada pula yang bersifat sekunder atau penunjang (auxiliary).

${ }^{6}$ Lexy J. Moleong, Metodologi Penelitian Kualitatif Edisi Revisi, Remaja Rosdakarya, Bandung, 2002, hlm. 103. ${ }^{7}$ Jimly Asshiddiqie, Perkembangan dan Konsolidasi Lembaga Negara Pasca Reformasi, Sekretariat Jenderal dan Kepaniteraan Mahkaman Konstitusi RI, Jakarta, 2006, hlm. 106-118.

${ }^{8}$ Ibid., hlm. 49.

${ }^{9}$ Ibid.

${ }^{10}$ Ibid., hlm. 105. 
Di negara-negara demokrasi yang telah mapan, seperti Amerika Serikat dan Perancis, pada tiga dasawarsa terakhir abad ke-20, juga banyak bertumbuhan lembaga-lembaga negara baru. ${ }^{11}$ Lembaga-lembaga negara baru tersebut disebut sebagai state auxiliary organs atau state auxiliary institutions. Lembaga-lembaga tersebut bersifat penunjang. Di antara lembaga-lembaga itu ada juga yang disebut sebagai self-regulatory agencies, independent supervisory bodies, atau lembaga-lembaga yang menjalankan fungsi campuran (mix-function), ${ }^{12}$ antara fungsi-fungsi regulatif, administratif, dan pemberian sanksi yang biasanya dipisahkan tetapi justru dilakukan secara bersamaan oleh lembaga-lembaga tersebut. ${ }^{13}$

Oleh karena itu, Bappebti, berdasarkan teori yang telah disampaikan sebelumnya, merupakan lembaga negara penunjang di bawah Kementerian Perdagangan yang dibentuk dengan undang-undang yaitu Undang-Undang No. 10 Tahun 2011. Bila dikaji dengan mendasarkan kepada pendapat Jimly di atas, maka Bappebti merupakan lembaga negara yang menjalankan fungsi eksekutif, regulasi, dan quasi-judicative sekaligus. Ini dapat terlihat dari fungsi Bappebti yaitu menyelenggarakan kegiatan pembinaan, pengaturan, dan pengawasan sehari-hari kegiatan perdagangan berjangka dan bertanggungjawab kepada menteri. ${ }^{14}$ Fungsi eksekutif Bappebti meliputi pembinaan, regulasi yaitu menyelenggarakan pengaturan, dan quasi-judicative yaitu pengawasan sehari-hari kegiatan perdagangan berjangka.

Peraturan Kepala Bappebti No. 99/Bappebti/Per/11/2012 tentang Penerimaan Nasabah secara Elektronik On-Line di Bidang Perdagangan Berjangka Komoditi yang dirubah dengan Peraturan Kepala Bappebti No. 107/Bappebti/Per/11/2013 merupakan peraturan pelaksana Pasal 50 ayat (6) Undang-Undang No. 10 Tahun 2011.15 Perjanjian pemberian amanat merupakan

${ }^{11}$ Ibid., hlm. 8.

${ }^{12}$ Ibid.

${ }^{13}$ Lembaga-lembaga tersebut bersifat independen dan memiliki fungsi regulasi dalam Ian Bartle dan Peter Vass, Self-Regulatory and the Regulatory State (A Survey of Policy and Practice), Centre for the Study of Regulated Industries, University of Bath.

${ }^{14}$ Pasal 4 Undang-Undang No. 10 Tahun 2011.

${ }^{15}$ Pasal 1 Surat Keputusan Bappebti No. 99/BAPPEBTI/PER/11/2012 tentang Penerimaan Nasabah secara Elektronik On-Line di Bidang Perdagangan Berjangka Komoditi untuk Melindungi Nasabah tidak berjalan efektif. Nasabah tidak dapat memperoleh perlindungan hukum sebagaimana seharusnya. Ketentuan dan persyaratan yang berlaku (Term of Services) agar nasabah memperoleh informasi secara benar dalam Perdagangan Berjangka Komoditi tidak mudah dipahami oleh Nasabah. Selain itu, tidak semua faktor penegakan hukum juga 
bagian dari serangkaian perdagangan berjangka melalui sistem elektronik. ${ }^{16}$ Penerimaan Nasabah secara elektronik on-line merupakan suatu proses yang meliputi pemahaman dan pengisian aplikasi pembukaan rekening transaksi; pernyataan adanya resiko; perjanjian pemberian amanat; dan pernyataan telah melakukan simulasi Perdagangan Berjangka dan peraturan perdagangan (trading rules) yang kesemuanya dilakukan secara elektronik.

Penerimaan Nasabah secara elektronik on-line hanya dapat dilakukan oleh Pialang Berjangka yang telah mendapat Penetapan dari Bappebti. Penetapan itu hanya dapat diberikan kepada Pialang Berjangka yang memenuhi persyaratan:17 pertama, tidak melanggar ketentuan tentang persyaratan keuangan minimum dan kewajiban pelaporan keuangan selama 1 (satu) tahun terakhir; kedua, memiliki sistem aplikasi penerimaan Nasabah secara elektronik on-line; dan ketiga, memiliki Standar Operasional Prosedur dalam rangka penerimaan Nasabah secara elektronik on-line.

Penerimaan Nasabah secara Elektronik On-Line di Bidang Perdagangan Berjangka Komoditi dapat dilakukan untuk pelaksanaan penerimaan Nasabah untuk transaksi Kontrak Berjangka dan/atau Kontrak Derivatif dalam Sistem Perdagangan Alternatif. ${ }^{18}$ Pialang Berjangka hanya dapat menerima calon Nasabah secara elektronik on-line setelah calon Nasabah yang bersangkutan menerima dan menyetujui isi Dokumen Perjanjian Pemberian Amanat, Dokumen Pernyataan Adanya Resiko, pilihan tempat penyelesaian perselisihan, peraturan perdagangan (trading rules), Kontrak Berjangka, Kontrak Derivatif Syariah dan/atau Kontrak Derivatif lainnya yang diperdagangkan, serta peraturan dan tata tertib sistem perdagangan elektronik on-line.

Bappebti memiliki kewajiban untuk melakukan sosialisasi terutama kepada investor agar memiliki pengetahuan tentang Bursa Berjangka. Namun, sosialisasi ini tidak akan berhasil secara optimal, bila investor tidak proaktif untuk menggali

\footnotetext{
berjalan dengan baik, misalnya saat penandatanganan amanat tidak dilakukkan sendiri oleh pialang berjangka, namun diwakilkan kepada marketing. Lihat Syahviera Nabhiella Putri, "Efektifitas Pasal 1 Surat Keputusan Bappebti No. 99/Bappebti/Per/11/2012 tentang Penerimaan Nasabah secara Elektronik On-Line di Bidang Perdagangan Berjangka Komoditi untuk Melindungi Nasabah (Studi di PT Millenium Penata Futures", Skripsi, Kementerian Pendidikan dan Kebudayaan, Fakultas Hukum. Universitas Brawijaya. 2012.

16Pasal 1 ayat (1) Peraturan Bappebti No. 107 Tahun 2013.

${ }^{17}$ Pasal 1 Peraturan Bappebti No. 107 Tahun 2013.

18Penelitian ini hanya membatasi pada pembahasan tentang transaksi Kontrak Berjangka.
} 
informasi dari berbagai sumber. Untuk saat ini, informasi mendasar tentang Bursa Berjangka dengan mudah dapat diakses di website Bappebti. Dengan mengunjungi website Bursa Berjangka atau Bappebti, investor dapat meminta informasi dan data kepada perpustakaan tentang bursa berjangka. Selain itu, investor dapat juga memperoleh informasi dan data dari pialang atau wakil pialang berjangka saat calon investor atau investor akan melakukan investasi di Bursa Berjangka melalui Perusahaan Pialang Berjangka.Informasi itu wajib disampaikan secara benar dan akurat, sesuai dengan peraturan perundang-undangan, di bawah pengawasan Bappebti. ${ }^{19}$

\section{Keabsahan dan Kekuatan Mengikat Kontrak Standar bagi Para Pelaku Perdagangan Berjangka Komoditi}

Berdasarkan konsep pembangunan dalam kaitannya dengan peran hukum dalam ekonomi pasar, salah satu yang berkaitan dengan penelitian ini adalah dalam perdagangan berjangka komoditi dimana konsep itu belum terimplementasi dengan baik. Misalnya, terdapat ketidakpastian dalam pengaturan tentang kewenangan Bappebti sebagai otoritas di bursa berjangka komoditi. Antara Undang-Undang yang memberikan kewenangan kepada Bappebti dan regulasi yang dibuat oleh Bappebti terdapat substansi yang asimetris. Ini, antara lain terdapat dalam kontrak baku yang berasal dari Lampiran 2 Peraturan Kepala Bappebti No. 107/BAPPEBTI/PER/11/2013, Formulir No. 107.PBK.05.1 tentang Perjanjian Pemberian Amanat secara Elektronik On-Line untuk Transaksi Kontrak Berjangka.

Dalam transaksi bisnis sangat lazim dipergunakan kontrak tertulis yang dikenal dengan kontrak baku atau standar. Namun demikian, tetap terdapat pro dan kontra yang timbul diantara para pakar hukum atas eksistensi kontrak baku itu. Bagi yang kontra, dan menolak kehadiran kontrak baku, karena dinilai;20 kedudukan pelaku usaha di dalam kontrak baku sama seperti pembentuk undangundang swasta (legio particuliere wetgever). Kontrak baku merupakan kontrak paksa (dwangcontract). ${ }^{21}$

\footnotetext{
${ }^{19}$ Amanah Pasal 50 ayat (1) - (6) Undang-Undang No. 10 Tahun 2011.

${ }^{20}$ Rachmadi Usman, Aspek-Aspek Hukum Perbankan di Indonesia, Gramedia Pustaka Utama, Jakarta, 2001, hlm. 265.

${ }^{21}$ Korea Fair Trade Commission, Adhesion Contract Review, http://www.ftc.go.kr/eng/policyarea/ consumerpolicy.jsp?pageId=0202, diakses tanggal 6 November 2016
} 
Dalam hal ini, kontrak baku dianggap meniadakan keadilan, karena hanya salah satu pihak yang membuat isi kontrak, sedangkan pihak lain hanya dapat menerima atau menolak isi kontrak. Sebaliknya, beberapa pakar hukum menerima kehadiran kontrak baku sebagai suatu kontrak, dengan argumentasi: Pertama, kontrak baku diterima sebagai kontrak berdasarkan fiksi adanya kemauan dan kepercayaan (ictie van wil en vertrouven) bahwa para pihak mengikatkan diri dalam kontrak itu; Kedua, setiap pihak yang menandatangani kontrak bertanggung jawab atas isi dan apa yang ditandatanganinya; Ketiga, kontrak baku mempunyai kekuatan mengikat, berdasarkan kebiasaan (gebruk) yang berlaku di dalam masyarakat dan lalu lintas perdagangan.22

Kehadiran Peraturan Kepala Bappebti No. 107/Bappebti/Per/11/2013 pada dasarnya tidak dalam situasi dan persyaratan teoritis berikut ini. Bahwasanya regulasi pada bursa berjangka komoditi tidak bergantung kepada tiga alasan mendasar berikut, yang sebenarnya telah diatur dalam Undang-Undang No. 10 Tahun 2011 yaitu:23 Pertama, regulator harus menunjuk (berlaku, memberikan lisensi) kontrak komoditas sebelum perdagangan yang sebenarnya dan secara berkala meninjau kontrak dan dapat menarik penunjukan setiap saat; Kedua, batasan "spekulatif" ditetapkan pada ukuran posisi dan volume perdagangan harian yang para pedagang dapat melakukan, dengan pengecualian tertentu; Ketiga, regulator memonitor perkembangan Perdagangan Berjangka Komoditi dan pasar tunai setiap hari dengan tujuan mencegah aktivitas yang akan menyebabkan manipulasi harga, terutama selama fase likuidasi setiap kontrak bulan.

Peraturan Kepala Bappebti No. 107/Bappebti/Per/11/2013 mengintervensi hubungan kontraktual para pihak yang akan terlibat dalam perdagangan di bursa berjangka. Semestinya, campur tangan atau intervensi Bappebti, sebagai lembaga pengawas yang merupakan kepanjangan tangan Pemerintah pada sektor privat, dilakukan guna mencapai tujuan Undang-Undang No. 10 Tahun 2011. Campur

\footnotetext{
${ }^{22}$ Sifat kontrak standar yang mengikat bagi para pihak ini salah satunya ditunjukan dalam kasus Upton v. Tribilcock dan Lewis v. Great Western Ry dimana kontrak dianggap mengikat para pihak ketika salah satu pihak telah menandatangani kontrak tersebut meskipun tidak membaca kontrak terlebih dahulu. Pengadilan Amerika secara konsisten telah menerapkan aturan ini. lihat John J. A. Burke, "Contract as Commodity: A Nonfiction Approach”, Seton Hall Legislative Journal, Seton Hall University Law Center, 2000.

${ }^{23}$ Gary L. Seevers, "Government Regulation and the Futures Markets," http://ageconsearch.umn.edu/ bitstream/32171/1/01010021.pdf, hlm. 24, diakses tanggal 6 November 2016
} 
tangan itu dapat berupa kebijakan ekonomi seperti promosi ekspor, perlindungan sektor komoditas, dan stabilisasi harga; maupun kebijakan yang mengamankan kepentingan masyarakat, seperti pengentasan kelaparan dan distribusi pendapatan yang merata. Intervensi di bursa berjangka seperti itu, dapat berupa diskresi atau otomatis (sering disebut sebagai rules-based), dan dapat diinisiasi oleh bursa berjangka sebagai Self Regulatory Organization (SRO) atau regulator yang mengawasi pasar. Diskresi dalam bursa berjangka biasanya melibatkan, membatasi, menangguhkan, atau menghentikan perdagangan tertentu kontrak berjangka. Pemerintah juga melakukan intervensi di pasar berjangka dengan cara yang luas untuk mempengaruhi kas keseluruhan dan pasar berjangka. Intervensi ini dapat mencakup embargo, kontrol harga, kuota, kewajiban hukum, pembelian langsung dari stok penyangga, dan langkah-langkah kebijakan-berdampak harga lainnya. ${ }^{24}$

Kajian sejarah atas intervensi pemerintah ke dalam pasar berjangka mengungkapkan bahwa, aturan berbasis intervensi dapat sukses dalam ekonomi pasar, namun intervensi diskresi sering gagal untuk mencapai proyeksi tujuannya. Intervensi diskresi sering menghasilkan berbagai konsekuensi yang harus dibayar mahal oleh pemerintah dan berbahaya bagi mayoritas pelaku yang bergerak di bidang produksi dan pemasaran komoditas yang ditargetkan. Untuk itu, dalam lingkup hukum, otoritas pengawas atau perdagangan dapat mengambil aksi diskresi selama berada dalam situasi yang dirasakan darurat, seperti peristiwa politik yang ekstrim, kendala logistik, kemacetan pasar, atau bencana alam. Tindakan diskresi termasuk suspensi atau penghentian perdagangan, pembatasan harga, perdagangan untuk likuidasi saja, atau penangguhan bagi anggota bursa untuk menentukan apakah melanggar aturan dan atau bertindak dengan cara yang merugikan perdagangan. ${ }^{25}$

Untuk itu, berkaitan dengan perdagangan komoditi hal penting ketika lembaga pengawas akan mengevaluasi peraturan pasar adalah untuk memperjelas

\footnotetext{
${ }^{24}$ Kate Hathaway, The Potential Effects of Government Intervention in a Market Economy, Financial Markets International of Washington, DC and Mumbai, India. April 2007, hlm. 3-4.

${ }^{25}$ Oral Testimony of Walter L. Lukken, Commissioner, U. S. Commodity Futures Trading Commission before the Committee on Agriculture United States House of Representatives, April 27, 2006.
} 
tujuan suatu regulasi yang dimaksud hanyalah untuk memajukan pasar, tolok ukurnya adalah tujuan yang tercantum dalam undang-undang yang mengatur tentang pasar itu. Apa karakteristik pasar yang lembaga pengawas berusaha untuk dorong? Efisiensi? Adil dan akses yang terbuka? Fenomena apa yang diinginkan untuk dicegah atau dihilangkan? Penipuan, manipulasi, atau praktik yang tidak adil lainnya? Ketidakstabilan sistemik? Tanpa jawaban eksplisit untuk pertanyaanpertanyaan ini, peraturan lembaga pengawas (apalagi yang sifatnya interventif) tidak mungkin efektif. Lebih mungkin, itu akan membuktikan tidak perlu, memberatkan, dan bahkan mungkin bertentangan dengan tujuan undang-undang dibuat. Karena, sekali tujuan dalam undang-undang telah ditentukan secara jelas, maka regulasi di bawahnya seharusnya untuk melaksanakan dan mengevaluasi, apakah memang diperlukan untuk tujuan dimaksud.

Apakah peraturan pemerintah (lembaga pengawas) diperlukan, dan jika demikian, apa bentuknya? Peraturan yang optimal, sangat bergantung pada karakteristik pasar. Pendekatan regulasi pasar keuangan bahwa "satu ukuran cocok untuk semua" hampir tidak pernah tepat. Tingkat dan jenis peraturan diperlukan, tergantung pada jenis instrumen yang diperdagangkan, jenis pelaku pasar, dan sifat hubungan antara pelaku pasar. Sebagai contoh, peraturan pemerintah yang dirancang untuk melindungi investor ritel dari penipuan atau kebangkrutan broker tidak mungkin diperlukan-- dan hampir pasti menjadi sub optimal - jika diterapkan ke pasar dimana investor-investor besar aktif bertransaksi. ${ }^{26}$

Secara legal formal, baik materi muatan Peraturan Kepala Bappebti, dan Lampiran 2 Peraturan Kepala Bappebti telah memenuhi ketentuan sebagaimana diatur dalam Undang-Undang No. 12 Tahun 2011 tentang Pembentukan Peraturan Perundang-Undangan. Pada Bab XII Ketentuan Lain-Lain secara eksplisit mengatur bahwa "Teknik penyusunan dan/atau bentuk yang diatur dalam Undang-Undang ini berlaku secara mutatis mutandis bagi teknik penyusunan dan/atau bentuk Keputusan Presiden, Keputusan Pimpinan Majelis

${ }^{26}$ Alan Greenspan, Some Considerations As A Guide for Government Decisions on Regulating the Financial Markets Remarks, the Financial Markets Conference of the Federal Reserve Bank of Atlanta, Coral Gables, Florida on 21/2/97, http://www.bis.org/review/r970227a.pdf. 
Permusyawaratan Rakyat, Keputusan Pimpinan DPR, Keputusan Pimpinan DPD, Keputusan Ketua Mahkamah Agung, Keputusan Ketua Mahkamah Konstitusi, Keputusan Ketua Komisi Yudisial, Keputusan Kepala Badan Pemeriksa Keuangan, Keputusan Gubernur Bank Indonesia, Keputusan Menteri, Keputusan Kepala Badan, Keputusan Kepala Lembaga, atau Keputusan Ketua Komisi yang setingkat, Keputusan Pimpinan DPRD Provinsi, Keputusan Gubernur, Keputusan Pimpinan DPRD Kabupaten/Kota, Keputusan Bupati/Walikota, Keputusan Kepala Desa atau yang setingkat."27

Selanjutnya Lampiran 2 Peraturan Kepala Bappebti telah sesuai dengan ketentuan sebagaimana dicantumkan dalam huruf F. Lampiran angka 192 - 197 Undang-Undang No. 12 Tahun 2011. Pada angka 192 ditentukan bahwa “Dalam hal Peraturan Perundang-undangan memerlukan lampiran, hal tersebut dinyatakan dalam batang tubuh bahwa lampiran dimaksud merupakan bagian yang tidak terpisahkan dari Peraturan Perundang-undangan." Berkaitan dengan hal itu, dalam Lampiran 2 Peraturan Kepala Bappebti dapat ditemukan: "Fitur-fitur dalam huruf b sampai $h$ di atas wajib berpedoman sesuai dengan Formulir No. 107.PBK.01 sampai No. 107.PBK.07 sebagaimana tercantum dalam Lampiran 2 Peraturan Kepala Bappebti yang merupakan bagian yang tidak terpisahkan dari Peraturan Kepala Bappebti ini."

Persoalannya adalah, bila dalam Lampiran Peraturan Kepala Bappebti ternyata berisi kontrak standar yang di dalamnya mengandung klausula yang tidak adil, membebankan kewajiban dan atau risiko pada salah satu pihak, apakah peraturan demikian sah dan mengikat bagi para pihak dalam kontrak untuk melaksanakannya? Hal yang terpenting adalah bukan esensi dari suatu kontrak dikategorikan sebagai kontrak baku, namun bagaimana agar kontrak baku itu memuat hak dan kewajiban yang seimbang di antara para pihak sehingga terjaminnya keadilan dan kepastian hukum. Dalam arti masing-masing pihak dalam membuat kontrak memiliki kewenangan untuk bersama-sama membuat isi kontrak, yang tentunya memuat hak dan kewajiban yang seimbang.

${ }^{27}$ Undang-Undang No. 12 Tahun 2011. 
Jawaban atas masalah itu tidak dapat ditemukan dalam peraturan yang secara khusus mengatur Perdagangan Berjangka Komoditi. Untuk itu, dengan menggunakan logika berpikir secara argumentum per analogiam atau sering disebut analogi, 28 maka peristiwa yang berbeda namun serupa, sejenis atau mirip yang diatur dalam Lampiran 2 Peraturan Kepala Bappebti itu dapat ditemukan dalam Undang-Undang No. 8 Tahun 1999 tentang Perlindungan Konsumen. Pelaku usaha dalam menawarkan barang dan/atau jasa yang ditujukan untuk diperdagangkan dilarang membuat atau mencantumkan klausula baku pada setiap dokumen dan/atau perjanjian apabila: Pertama, menyatakan pengalihan tanggung jawab pelaku usaha; Kedua, menyatakan bahwa pelaku usaha berhak menolak penyerahan kembali barang yang dibeli konsumen; Ketiga, menyatakan bahwa pelaku usaha berhak menolak penyerahan kembali uang yang dibayarkan atas barang dan/atau jasa yang dibeli oleh konsumen; Keempat, menyatakan pemberian kuasa dari konsumen kepada pelaku usaha baik secara langsung maupun tidak langsung untuk melakukan segala tindakan sepihak yang berkaitan dengan barang yang dibeli oleh konsumen secara angsuran; Kelima, mengatur perihal pembuktian atas hilangnya kegunaan barang atau pemanfaatan jasa yang dibeli oleh konsumen; Keenam, memberi hak kepada pelaku usaha untuk mengurangi manfaat jasa atau mengurangi harta kekayaan konsumen yang menjadi objek jual beli jasa; Ketujuh, menyatakan tunduknya konsumen kepada peraturan yang berupa aturan baru, tambahan, lanjutan dan/atau pengubahan lanjutan yang dibuat sepihak oleh pelaku usaha dalam masa konsumen memanfaatkan jasa yang dibelinya; dan Kedelapan, menyatakan bahwa konsumen memberi kuasa kepada pelaku usaha untuk pembebanan hak tanggungan, hak gadai, atau hak jaminan terhadap barang yang dibeli oleh konsumen secara angsuran. ${ }^{29}$

Pelaku usaha dilarang mencantumkan klausula baku yang letak atau bentuknya sulit terlihat atau tidak dapat dibaca secara jelas, atau yang pengungkapannya sulit dimengerti. Setiap klausula baku yang telah ditetapkan oleh pelaku usaha pada dokumen atau perjanjian yang memenuhi ketentuan dinyatakan batal demi hukum. Untuk selanjutnya, pelaku usaha wajib 
menyesuaikan klausula baku yang bertentangan dengan Undang-undang ini. ${ }^{30}$ Bagaimana melakukan pembatalan kontrak, padahal format dan substansi kontrak itu merupakan perintah peraturan dari lembaga pengawas (Bappebti)? Langkah yang harus dilakukan adalah, terlebih dahulu mengajukan judicial review ke Mahkamah Agung. Ini sesuai dengan kewenangan Mahkamah Agung terkait dengan judicial review, yaitu: ${ }^{31}$ Pertama, MA mempunyai wewenang menguji peraturan perundang-undangan di bawah undang-undang terhadap undangundang; Kedua, MA menyatakan tidak sah peraturan perundang-undangan di bawah undang-undang atas alasan bertentangan dengan peraturan perundangundangan yang lebih tinggi atau pembentukannya tidak memenuhi ketentuan yang berlaku.

Permohonan judicial review itu hanya dapat dilakukan oleh pihak yang menganggap haknya dirugikan oleh berlakunya peraturan perundang-undangan di bawah undang-undang, yaitu: 32 Pertama, perorangan warga negara Indonesia; Kedua, kesatuan masyarakat hukum adat sepanjang masih hidup dan sesuai dengan perkembangan masyarakat dan prinsip Negara Kesatuan Republik Indonesia yang diatur dalam undang-undang; atau c) badan hukum publik atau badan hukum privat.

\section{Penutup}

Berdasarkan pembahasan di atas, maka dapat dikemukakan dua kesimpulan. Pertama, Lampiran No. 2 Peraturan Kepala Bappebti No. 107 Tahun 2013 berisi Formulir-Formulir Standar, antara lain Perjanjian Pemberian Amanat secara Elektronik On-Line antara Nasabah dan Pialang Berjangka merupakan bentuk intervensi Pemerintah (melalui lembaga pengawas) ke dalam hubungan kontraktual, yang di dalamnya memuat klausula pembatasan dan pelepasan tanggung jawab salah satu pihak, yaitu Pialang Berjangka. Meskipun intervensi Pemerintah ini dilakukan oleh Bappebti dalam kapasitasnya sebagai state auxiliary organ, namun peraturan itu menimbulkan ketidakadilan bagi investor. Padahal

${ }^{30}$ Pasal 18 ayat (2) dan (3) Undang-Undang No. 8 Tahun 1999.

${ }^{31}$ Pasal 31 ayat (1 dan (2) Undang-Undang No. 5 Tahun 2004 tentang Perubahan atas Undang-Undang No. 14 Tahun 1985 tentang Mahkamah Agung.

32Pasal 31A ayat (2) Undang-Undang No. 3 Tahun 2009. 
berjalannya pasar dalam perdagangan berjangka komoditi sangat dipengaruhi oleh investor sebagai pihak yang membeli komoditas yang diperdagangkan. Kedua, kontrak yang demikian itu seharusnya batal demi hukum. Intervensi lembaga pengawas ke dalam hubungan kontraktual para pelaku pasar seharusnyalah dalam kerangka mencapai tujuan Undang-Undang No. 10 Tahun 2011. Namun pembatalan kontrak itu dapat dilakukan dengan terlebih dahulu mengajukan judicial review ke Mahkamah Agung, sesuai dengan kewenangan Mahkamah Agung terkait dengan judicial review terhadap peraturan perundang-undangan di bawah undang-undang.

\section{Daftar Pustaka}

\section{Buku}

Asshiddiqie, Jimly, Perkembangan dan Konsolidasi Lembaga Negara Pasca Reformasi, Sekertariat Jenderal dan Kepaniteraan Mahkaman Konstitusi RI, Jakarta, 2006

Bartle, Ian dan Peter Vass, Self-Regulatory and the Regulatory State (A Survey of Policy and Practice), Centre for the Study of Regulated Industries, University of Bath.

Hoffman, Future Trading upon Organized Commodity Markets in the United States, 1932.

Mertokusumo, Sudikno, Penemuan Hukum, Universitas Atmajaya Yogyakarta, 2010.

Moleong, Lexy J., Metodologi Penelitian Kualitatif Edisi Revisi, Remaja Rosdakarya, Bandung, 2002.

Usman, Rachmadi, Aspek-Aspek Hukum Perbankan di Indonesia, Gramedia Pustaka Utama, Jakarta, 2001.

Hathaway, Kate, The Potential Effects of Government Intervention in a Market Economy, Financial Markets International of Washington, DC and Mumbai, India. April 2007.

Oral Testimony of Walter L. Lukken, Commissioner, U. S. Commodity Futures Trading Commission before the Committee on Agriculture United States House of Representatives, April 27, 2006.

\section{Hasil Penelitian/Tugas Akhir}

Nabhiella Putri, Syahviera, "Efektifitas Pasal 1 Surat Keputusan Bappebti No. 99/Bappebti/Per/11/2012 tentang Penerimaan Nasabah secara Elektronik On-Line di Bidang Perdagangan Berjangka Komoditi untuk Melindungi Nasabah (Studi di PT Millenium Penata Futures", Skripsi, Kementerian 
Pendidikan dan Kebudayaan, Fakultas Hukum. Universitas Brawijaya. 2012.

\section{Artikel Jurnal}

Burke, John J. A. "Contract as Commodity: A Nonfiction Approach," Seton Hall Legislative Journal, Seton Hall University Law Center, 2000.

Federal Regulation of Commodity Future Trading, 60 Yale Law Journal 822, Mei 1951.

Note, "Prevention of Commodity Futures Manipulation under the Commodity Exchange Act," 54 Harvard Law Review 1373, Juni 1941.

\section{Internet}

Korea Fair Trade Commission, Adhesion Contract Review, http:/ /www.ftc.go.kr/ eng/policyarea/consumerpolicy.jsp?pageId=0202, diakses tanggal 2 November 2016.

Seevers, Gary L., "Government Regulation and the Futures Markets," http:/ /ageconsearch.umn.edu/bitstream/32171/1/01010021.pdf, diakses tanggal 3 November 2016.

Greenspan, Alan, Some Considerations As A Guide for Government Decisions on Regulating the Financial Markets Remarks, the Financial Markets Conference of the Federal Reserve Bank of Atlanta, Coral Gables, Florida on 21/2/97, http:/ / www.bis.org/review/r970227a.pdf., diakses tanggal 3 November 2016.

\section{Peraturan Perundang-undangan}

Undang-Undang No. 10 Tahun 2011 tentang Perubahan atas Undang-Undang No. 31 Tahun 1997 tentang Perdagangan Berjangka Komoditi (Lembaran Negara Republik Indonesia Tahun 2011 Nomor 79, Tambahan Lembaran Negara Nomor 5232)

Undang-Undang No. 12 Tahun 2011 tentang Pembentukan Peraturan PerundangUndangan Komoditi (Lembaran Negara Republik Indonesia Tahun 2011 Nomor 82, Tambahan Lembaran Negara Nomor 5234)

Undang-Undang No. 3 Tahun 2009 tentang Perubahan Kedua atas UndangUndang No. 14 Tahun 1985 tentang Mahkamah Agung. Komoditi (Lembaran Negara Republik Indonesia Tahun 2009 Nomor 3, Tambahan Lembaran Negara Nomor 4958)

Undang-Undang No. 5 Tahun 2004 tentang Perubahan atas Undang-Undang No. 14 Tahun 1985 tentang Mahkamah Agung. Komoditi (Lembaran Negara Republik Indonesia Tahun 2004 Nomor 9, Tambahan Lembaran Negara Nomor 4359) 
Undang-Undang No. 8 Tahun 1999 tentang Perlindungan Konsumen. Komoditi (Lembaran Negara Republik Indonesia Tahun 1999 Nomor 22, Tambahan Lembaran Negara Nomor 3821).

Peraturan Pemerintah No. 9 Tahun 1999 tentang Penyelenggaraan Perdagangan Berjangka Komoditi.

Peraturan Kepala Bappebti No. 107/Bappebti/Per/11/2013 tentang Perubahan atas Peraturan Kepala Bappebti No. 99/Bappebti/Per/11/2012 tentang Penerimaan Nasabah secara Elektronik On-Line di Bidang Perdagangan Berjangka Komoditi.

Surat Keputusan Bappebti No. 99/Bappebti/Per/11/2012 tentang Penerimaan Nasabah secara Elektronik On-Line di Bidang Perdagangan Berjangka Komoditi untuk Melindungi Nasabah. 